\title{
黒毛和種における全国的な種牛評価の可能性および 数学モデルに関する研究
}

\author{
小谷 基* ${ }^{*}$ 中岡博史 ${ }^{*}$ 成田 暁・揖斐隆之 ${ }^{1} \cdot$ 佐々江洋太郎 ${ }^{1} \cdot$ 佐々木義之 \\ 京都大学大学院農学研究科, 京都市左京区 606-8502 \\ 1 (有)安愚楽共済牧場, 黒磯市 325-0033
}

（2003. 12. 24 受付，2004.5.24受理）

\begin{abstract}
要 約 全国的な種牛評価の可能性を遺伝的結合度および遺伝率推定値の点から検討し, その結果を ふまえて全国的な種牛評価のための最適な数学モデルに関して検討した. 1997〜2002 年までに全国に分 布する (有)安愚楽共済牧場傘下の肥育農家から出荷された黒毛和種肥育牛のフィールド記録を用いた。 数学モデルとして，母数効果の取り上げ方が異なる 6 つのモデルを設定し，産肉性形質に関する遺伝率 を推定し，育種価を予測した。肥育農家を単位とする分集団間の遺伝的結合度が確認できたことおよび 遺伝率の推定值が中程度であったことから，全国規模での種牛評価が可能であると推察される。また， 予測育種価の予測誤差分散 (PEV), 赤池の情報量規準 (AIC) および自由度調整済寄与率を指標としてモ デルの選択を行った結果，全ての母数効果を組み合わせ効果として取り上げたモデルもしくは性の効果 のみを組み合わせ効果から外したモデルが最適なモデルであると推察される．種牛評価を全国規模に拡 大することで，より効率的な育種改良を行うことができると考えられる.
\end{abstract}

日本畜産学会報, 75 (3)：353-361, 2004

乳牛では，複数の国や地域に種雄牛の供用範囲が拡大 し，現在までに種牛評価が全国的，さらには世界的な規 模で行われるようになっている（磯貝ら $1993 ;$ W Weigel ら 2001).一方, わが国の肉牛においては, 肥育農家から 枝肉市場に出荷された肥育牛のフィールド記録を用いた BLUP 法（Henderson 1973）による予測育種価が，標準 的な種牛評価の基準となったことで産肉性の遺伝的改良 が急速に向上している.しかし，従来からの県単位での 育種から (社) 家畜改良事業団による平準化事業をはじ め育種の広域化が進んでいるにもかかわらず, 複数の県 のフィールド記録をまとめて, 県を超えて種牛を評価す るという広域での種牛評価はほとんど行われていない. 今後国際競争力をつけていく上で，肉牛の場合も広域 での種牛評価が必要になってくると考えられるが，広域 での種牛評価を行う場合, 地域間の遺伝的結合度が評価 の正確度に大きく関与し，遺伝的結合度が高くなければ 正確な評価を行うことはできない (Woodら 1991 ; Kennedy と Trus 1993).

この点で, (有)安愚楽共済牧場は全国各地に繁殖雌牛 群を保有し, これらの雌牛に対して（社）家畜改良事業団 の種雄牛をはじめ, 全国各地の種雄牛を交配し, 生まれ た後代牛を肥育している.さらに, 全国各地から肥育素
牛を導入し，地場産の肥育素牛とともに肥育している. したがって，これらの肥育牛の記録を利用することに よって, 全国的な種牛評価の可能性があると考えられる.

そこで,（有)安愚楽共済牧場で収集された黒毛和種肥 育牛の枝肉市場記録について，そのデー夕構造，遺伝的 結合度, 産肉性形質に関する遺伝率推定値などの点から 全国的な種牛評価の可能性を検討した。ついで, 解析し たデー夕構造をふまえて, 最適な数学モデルに関して検 討を行った。

\section{材料および方法}

\section{1. データ}

材料として，1997〜2002 年までに全国に分布する (有) 安愚楽共済牧場夎下の 130 肥育農家から 31 枝肉市 場に出荷された黒毛和種肥育牛 50,271 頭のフィールド 記録を用いた。分析対象とする産肉性形質として脂肪交 雑基準（Beef Marbling Standard Number），枝肉重量， ロース芯面積, バラの厚さおよび皮下脂肪厚（以下それ ぞれ, BMS No., CW, REA, RT およびSFT と略す) の計 5 形質を取り上げた.

\section{2. 遺伝的結合度に関する検討}

全国的な種牛評価のために最低限必要な遺伝的結合が

*両著者は本研究に対して同等に寄与した。

連絡者：佐々木義之（fax：075-753-6340,e-mail：sasaki@kais.kyoto-u.ac.jp） 
地域間に保たれているかどうかを以下の 2 点から検討し た。地域として，肉牛の育種においてもっとも重要な環 境要因であると考えられる肥育農家を取り上げること で，遺伝的結合度に関する最低限の検討は行えるものと した.まず，父牛に関する結合度の検討として，肥育農 家ペアごとに両農家に後代牛をもつ共通種雄牛の頭数を すべての肥育農家ペアに関して数えた。ついで，母牛に 関する結合度については，母牛を肥育牛の生産県ごとに まとめた肥育素牛生産県（以下生産県と称す）について 検討した。この生産県を種雄牛, 肥育農家を牛群とみな して，これらに有効な後代数 (RobertsonとRendel 1954) の考え方を応用して，肥育農家に関する生産県の有効な 肥育牛の頭数を式 (1) により算出した.

$$
n_{E j}=\sum_{i} n_{i j}\left(1-\frac{n_{i j}}{n_{i} \bullet}\right)
$$

ここで, $n_{E j}: \mathrm{j}$ 番目の生産県の有効な肥育牛の頭数, $n_{i j}$ : $\mathrm{i}$ 番目の肥育農家における j 番目の生産県の肥育牛の頭 数, $n_{i} \bullet$ : i 番目の肥育農家における肥育牛の頭数である. なお生産県とは, 肥育素牛の産地を意味すると同時に, 母牛の繋養地を県単位で一まとめにしたもので，それら が何らかの形での血縁で結ばれた一つの群を構成するも のとみなした。

\section{3. 数学モデルの設定および遺伝率推定と育種価予測}

分析データとして用いた記録は，一副次級あたり 5 頭 以上の肥育牛をもつ性・枝肉市場・出荷年・肥育農家の 組み合わせの副次級に属する個体，計 49,810 頭の記録 であり，それらの出荷年別性別分布は表1のとおりで あった.また, 血統情報は肥育牛から 2 世代遡った世代ま で調査した. その結果, 分析に用いた全個体数は114,056 頭となった.

まず，デー夕構造の解析として，母数効果のうち主効 果として取り上げる性, 枝肉市場, 出荷年, 肥育農家の 各環境要因間の肥育牛頭数クロス分布表をとり, 要因間 の結合度について検討した。その特徴をふまえて, 全国
的な種牛評価のための数学モデルとして表 2 に示すよう な6つのモデルを設定した.これらの 6 つのモデルは， それぞれ母数効果のうち主効果として取り上げる要因の 組み合わせ方が異なるモデルであり，それぞれの数学モ デルにおける組み合わせ効果は，一つの主効果としてモ デルに取り上げた.

次に, GLMTEST (Moriya ら 1998) を用いて, 混合モデ ルによる母数効果の有意性検定を行った。 その結果，母 数効果のうち主効果として取り上げたすべての要因がす ベての形質で有意であり，また共変量として取り上げた 肥育期間および肥育終了時日齢については, SFT を除く すべての形質で2次までの回帰が有意であった（P< 0.05).ただし, SFT の場合およびCW でモデル 4 とモデ ル 6 の場合は, 肥育終了時日齢に関して 1 次も2 次も有 意でなかった。これら $5 \%$ 水準で有意な変動が認められ た効果のみを数学モデルの中に含めた.

分散成分並びに遺伝率はREML法(Patterson とThompson 1971）により推定し，その計算には MTDFREML プ ログラム（Boldmanら 1995）を用いた.さらに得られた 遺伝率推定値を用いて, 単形質個体モデルの BLUP 法

Table 1. Distribution of fattened cattle by shipping years and sexes

\begin{tabular}{crrr}
\hline \hline \multirow{2}{*}{ Shipping year } & \multicolumn{3}{c}{ Number of fattened cattle } \\
\cline { 2 - 4 } & Steer & Heifer & Total \\
\hline 1997 & 2,564 & 1,981 & 4,545 \\
1998 & 5,007 & 3,992 & 8,999 \\
1999 & 4,011 & 2,107 & 6,118 \\
2000 & 5,642 & 4,489 & 10,131 \\
2001 & 6,252 & 4,412 & 10,664 \\
2002 & 5,786 & 3,567 & 9,353 \\
\hline Total & 29,262 & 20,548 & 49,810 \\
\hline
\end{tabular}

Table 2. Mathematical models used in this analysis

\begin{tabular}{|c|c|}
\hline Model 1 & $y_{i j k l m}=\mu+S_{i}+M_{j}+N_{k}+F_{1}+p_{1}\left(x_{i j k / m}-\bar{x}\right)+p_{2}\left(x_{i j k l m}-\bar{x}\right)^{2}+a_{1}\left(z_{i j k / m}-\bar{z}\right)+a_{2}\left(z_{i j k l m}-\bar{z}\right)^{2}+u_{m}+e_{i j k / m}$ \\
\hline Model 2 & $y_{i j k l m}=\mu+M F_{j l}+S_{i}+N_{k}+p_{1}\left(x_{i j k / m}-\bar{x}\right)+p_{2}\left(x_{i j k l m}-\bar{x}\right)^{2}+a_{1}\left(z_{i j k / m}-\bar{z}\right)+a_{2}\left(z_{i j k l m}-\bar{z}\right)^{2}+u_{m}+e_{i j k l m}$ \\
\hline Model 3 & $y_{i j k l m}=\mu+N F_{k l}+S_{i}+M_{j}+p_{1}\left(x_{i j k / m}-\bar{x}\right)+p_{2}\left(x_{i j k / m}-\bar{x}\right)^{2}+a_{1}\left(z_{i j k l m}-\bar{z}\right)+a_{2}\left(z_{i j k l m}-\bar{z}\right)^{2}+u_{m}+e_{i j k l m}$ \\
\hline Model 4 & $y_{i j k l m}=\mu+M N F_{j k l}+S_{i}+p_{1}\left(x_{i j k l m}-\bar{x}\right)+p_{2}\left(x_{i j k l m}-\bar{x}\right)^{2}+a_{1}\left(z_{i j k l m}-\bar{z}\right)+a_{2}\left(z_{i j k / m}-\bar{z}\right)^{2}+u_{m}+e_{i j k / m}$ \\
\hline Model 5 & $y_{i j k l m}=\mu+S M F_{i j l}+N_{k}+p_{1}\left(x_{i j k l m}-\bar{x}\right)+p_{2}\left(x_{i j k l m}-\bar{x}\right)^{2}+a_{1}\left(z_{i j k / m}-\bar{z}\right)+a_{2}\left(z_{i j k l m}-\bar{z}\right)^{2}+u_{m}+e_{i j k l m}$ \\
\hline Model 6 & $y_{i j k l m}=\mu+S M N F_{i j k l}+p_{1}\left(x_{i j k / m}-\bar{x}\right)+p_{2}\left(x_{i j k / m}-\bar{x}\right)^{2}+a_{1}\left(z_{i j k / m}-\bar{z}\right)+a_{2}\left(z_{i j k / m}-\bar{z}\right)^{2}+u_{m}+e_{i j k / m}$ \\
\hline
\end{tabular}

Where

$y_{i j k l m}$ : an observation for the carcass trait, $\mu$ : overall mean, $S_{i}$ : the fixed effect of $i$ th sex, $M_{j}$ : the fixed effect of $j$ th market, $N_{k}$ : the fixed effect of $k$ th shipping year, $F_{l}$ : the fixed effect of $/$ th fattening farm, $p_{1}$ and $p_{2}$ : linear and quadratic regression coefficients on fattening period, $x_{i j k / m}$ and $\bar{x}$ : fattening period and its average, respectively, $a_{1}$ and $a_{2}$ : linear and quadratic regression coefficients on slaughter age, $z_{i j k / m}$ and $\bar{z}$ : slaughter age and its average, respectively, $u_{m}$ : the additive genetic effect for an animal, $e_{i j k / m}:$ the random residual effect. 
（Henderson 1976）による育種価予測を行った.

全国評価に適した数学モデルを選択することの重要性 を示すために，以下の 2 項目について検討した．まず， 数学モデルが遺伝率推定值に及ぼす影響について検討し た. その方法として, 全デー夕から 6,800 頭を無作為抽出 する試行を10 回繰り返して 10 個のサンプル集団を作っ た。そして，そのサンプル集団が 5 頭以上の肥育牛をも つ性・枝肉市場・出荷年・肥育農家の組み合わせの副次 級に属する個体のみで構成されるように調整した後, そ れぞれの集団について推定した遺伝率に対して数学モデ ル間の Friedman 検定（市原 2001）を行った. Friedman 検定とはサンプル内で各モデルから得られた遺伝率推定 値の大きさに従って順位を付けて各モデルの順位和を求 め, モデル間で遺伝率推定値に有意差が認められるかを 検定する方法である.

$$
\chi_{r}^{2}=\frac{12}{n k(k+1)} \sum_{i=1}^{k} R_{i}^{2}-3 n(k+1)
$$

ここで, $n$ : サンプル集団の数 $(=10), k$ : モデルの数 $(=6), R_{i}$ : モデル $i$ の順位和である. フリードマン検定 の統計量 $\chi_{r}^{2}$ は式 (2)により算出され, $\chi_{r}^{2}$ が近似的に自由 度 $k-1$ の $\chi^{2}$ 分布に従うことを利用して確率を求めた。

ついで，種雄牛の予測育種価におけるモデル間の差を検 討した。

\section{4. 数学モデルの適合性の比較}

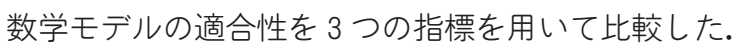
一つ目として，予測育種価の予測誤差分散（PEV）を用 いた.

$$
\rho_{a(E P D)}=\sqrt{\frac{1-P E V}{A_{i j} \sigma_{a}^{2}}}
$$

ここで, $A_{i i}$ : 分子血縁係数行列の $i$ 番目の個体に相当す る対角要素, $\sigma_{a}^{2}$ : 相加的遺伝分散である. 予測育種価の 正確度 $\left(\rho_{a}(E P D)\right)$ と PEV は式 (3) のような関係にあり (佐々木 1998), PEV が小さければ小さいほど予測育種 価の正確度は高く, モデルの適合性は高いといえる. 二 つ目として, 赤池の情報量規準 (AIC) を用いた。

$$
A / C=-2 \ln L+2 p
$$

ここで, InL : 最大対数尤度, $p:$ モデルに含まれる独立 変数の水準数である. AlC は式（4）のように算出され (Akaike 1973), AIC の值が最小となるモデルが最適なモ デルである. 三つ目として, 自由度調整済寄与率（以下 $R^{\prime 2}$ と略す）を用いた。

$$
\begin{aligned}
& R^{\prime 2}=R^{2}-\frac{p}{n-p-1}\left(1-R^{2}\right) \\
& R^{2}=\frac{\sum\left(\hat{y}_{i}-\bar{y}\right)^{2}}{\sum\left(y_{i}-\bar{y}\right)^{2}}
\end{aligned}
$$

ここで, $R^{2}$ : 寄与率 (決定係数), $p:$ 独立変数の水準数, $n:$ デー夕数, $y_{i}: i$ 番目の個体の観測值, $\hat{y}_{i}$ : 数学モデル ごとの $i$ 番目の個体の推定値, $\bar{y}$ : 観測值の算術平均であ
る. $R^{\prime 2}$ は式（5）のように算出され（丹後 2000), $R^{\prime 2}$ の 值が最大となるモデルが最適なモデルである.

\section{結果および考察}

(有)安愚楽共済牧場から枝肉市場に出荷された黒毛和 種肥育牛は, 表 1 に示すように 1997 年から 2002 年にわ たり，去勢牛および雌牛が共に持続的に出荷されてい る.

広域での種牛評価を行う場合, 遺伝的結合度が評価の 正確度に大きく関与し，地域間の遺伝的結合度が高けれ ば高いほどより正確な評価を行うことができる（Wood ら 1991 ; Kennedy と Trus 1993).この点に関して, Roso ら（2002）は，地域間で共通に後代牛をもつ種雄牛に基 づいて定義される直接的な遺伝的結合が，遺伝的結合度 の指標として有効であるとしている。そそこで，肥育農家 間の遺伝的結合度に関する検討としてまず，肥育農家ぺ アごとに両農家に後代牛をもつ共通種雄牛の頭数を調査

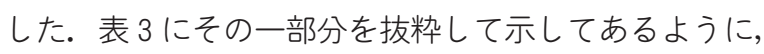
肥育農家ペア計 8,385ペア（肥育農家が計 130 戸）につ いて，ほとんどの肥育農家が他の肥育農家を相手にして 共通種雄牛をもち, 共通種雄牛をもたないペアはわずか 381 ペアであった. また, 共通種雄牛をもたないペア（例 えば表3では98 と 223）であっても，その他の肥育農家 に後代牛をもつ種雄牛を通じて遺伝的に結合していた。 以上より，父牛に関する肥育農家間の遺伝的結合度には 問題がないものと推察される.

一方, 肥育農家が父牛に関して遺伝的に結合していて も, 母牛側の遺伝的能力の優劣が肥育農家と交絡してい る場合には種牛評価に偏りを生じさせることが懸念され る. 雌牛の場合, 後代牛の数が少ないので, 種雄牛亡同 じように肥育農家ペアごとに両農家に後代牛をもつ共通 雌牛自身を数えてもあまり意味がない。そこで，母牛を

Table 3. Number of sires of which progeny appears commonly in each pair of fattening farms

\begin{tabular}{c|cccccccccc}
\hline \hline \multirow{2}{*}{ Fattening farm } & \multicolumn{7}{|c}{ Fattening farm $^{\text {a) }}$} \\
\cline { 2 - 9 } & 98 & 99 & 102 & 103 & 104 & 108 & 124 & 125 & 223 \\
\hline 97 & 7 & 11 & 3 & 1 & 2 & 5 & 3 & 4 & 3 \\
98 & & 21 & 14 & 31 & 34 & 8 & 14 & 10 & 0 \\
99 & & & 12 & 19 & 20 & 14 & 12 & 14 & 4 \\
102 & & & & 23 & 25 & 29 & 40 & 43 & 6 \\
103 & & & & & 86 & 14 & 18 & 20 & 1 \\
104 & & & & & & 15 & 20 & 23 & 1 \\
108 & & & & & & & 27 & 32 & 5 \\
124 & & & & & & & & 42 & 6 \\
125 & & & & & & & & & 8 \\
\hline
\end{tabular}

a) Code numbers of fattening farms are shown as a part of the whole. 
肥育牛の生産県ごとにグループ化し，そのグループによ る肥育農家間の遺伝的結合度を検討することにした。 そ の方法として, 有効な後代数 (Robertson と Rendel 1954）の考え方を応用して生産県の有効な肥育牛の頭数 を算出し, 表 4 に示した。 その結果, 有効な肥育牛の頭 数がゼロとなるような生産県はなく, また, 実頭数に比 較して有効な肥育牛の頭数があまり減少せず, 肥育農家 と生産県との間の結合度が保たれていることが分かっ た。ここでは, 肥育農家間の遺伝的結合度をみるという 意味から有効な後代数の形で示したが，二元配置におけ る二つの要因間の結合度をみるのと全く同じことである (佐々木 1989). 異なる点は, 遺伝的要因として取り上げ た生産県グループ内の雌牛が何らかの形で遺伝的につな がっている必要がある点である.この点に関して, 黒毛 和種では生産県全体が均一化し，一つの集団となりつつ あることが報告されている(野村ら 1987 ; 高柳ら 1996). また, 新しい生産県, 例えば沖縄や北海道などでは様々 な県から遺伝的寄与を受けており, 各県集団がさらに数 個の遺伝的グループに分類できることが示唆されていた （野村ら 1988）が，それらの県でも肉質の向上に対する 関心の高まりとともに特定の種雄牛に供用が集中してき ている.さらに, (社) 家畜改良事業団の種雄牛が広域で 供用されるようになっている.これらの点から, 各生産 県集団が均一な集団とはみなされないにしても，少なく とも母方祖父牛等を通じて同じ生産県の雌牛が大なり小 なり遺伝的につながっているものと考えられる．以上の
点から，母牛に関しても肥育農家間の遺伝的結合は最低 限保たれているものと推察される.

デー夕構造についてクロス分布表でみると，表1のよ うに出荷年と性は完全な交叉型デー夕であったが，その 他の組み合わせでは交叉型からずれた分布となり，記録 のない副次級が多くみられた. それぞれの組み合わせに おける記録のない副次級の割合を表 5 に示した。その結 果, 特に肥育農家別出荷市場別肥育牛頭数のクロス分布 は，デー夕構造が交叉型からはほど遠く，巣ごもり型に 近いものであった。この傾向は, 県単位のデー夕（佐々 木 1991）にはみられなかったもので，本データの大きな 特徵であった. また, 交叉型からずれたデー夕構造のた め, 性とその他の環境要因間以外の母数効果間の交互作 用効果の有意性を検討することはできなかったし，それ らの効果を説明変数としてモデルに取り上げることは適 当でないと考えられた。 そのため, 母数効果の組み合わ せ効果以外の主効果については，それらの間の交互作用 効果を取り上げないモデルのみを考えて, 表 2 に示した 6 つの数学モデルを設定した.

これらのモデルを用いて推定した産肉性形質の遺伝率 推定値を表 6 に示した。1988〜1994 年までに全国 24 道 府県（28 地域）で収集された約 70,000 頭の枝肉格付記録 から各県 (地域) 単位で得られた遺伝率推定値の重み付 け平均は, 脂肪交雑評点で 0.46 , 枝肉重量で $0.44, \square-$ ス芯面積で 0.45 , バラの厚さで 0.38 , 皮下脂肪厚で 0.35 であり（向井 1994），それらと比較するとBMS No. およ

Table 4. Observed and effective number of fattened cattle for a cow-calf produced prefecture

\begin{tabular}{c|cc}
\hline \hline $\begin{array}{c}\text { Cow-calf produced } \\
\text { prefecture }\end{array}$ & $\begin{array}{c}\text { Observed number of } \\
\text { fattened cattle }\end{array}$ & $\begin{array}{c}\text { Effective number of } \\
\text { fattened cattle }\end{array}$ \\
\hline Okinawa & 12,889 & $5,251.34$ \\
Kagoshima & 12,152 & $6,605.62$ \\
Hokkaido & 9,704 & $3,677.48$ \\
Miyazaki & 6,034 & $4,045.87$ \\
Iwate & 2,413 & $1,333.15$ \\
Fukushima & 1,709 & $1,090.27$ \\
Oita & 1,453 & 936.25 \\
Aomori & 1,208 & 564.38 \\
Miyagi & 1,078 & 793.08 \\
Tochigi & 619 & 493.94 \\
Kumamoto & 311 & 291.21 \\
Shimane & 242 & 224.87 \\
Nagasaki & 102 & 95.68 \\
Fukuoka & 88 & 83.69 \\
Yamagata & 42 & 41.03 \\
Okayama & 39 & 38.30 \\
Hyogo & 25 & 24.26 \\
\hline
\end{tabular}


Table 5. Proportion of the subclasses without record of fattened cattle

\begin{tabular}{cccc}
\hline \hline \multirow{2}{*}{$\begin{array}{c}\text { Combination of the } \\
\text { fixed effects }\end{array}$} & \multirow{2}{*}{$\begin{array}{c}\text { Total number of } \\
\text { subclasses }\end{array}$} & \multicolumn{2}{c}{ Subclasses with no records } \\
\cline { 3 - 4 } & $2 \times 6$ & Number & Percentage $(\%)$ \\
\hline sex $\times$ shipping year & $2 \times 31$ & 0 & 0.0 \\
sex $\times$ market & $2 \times 130$ & 2 & 3.2 \\
sex $\times$ fattening farm & $6 \times 31$ & 87 & 46.9 \\
shipping year $\times$ market & $6 \times 130$ & 364 & 46.8 \\
shipping year $\times$ fattening farm & $31 \times 130$ & 3,226 & 86.7 \\
market $\times$ fattening farm & &
\end{tabular}

Table 6. Heritability estimates for carcass traits obtained by the six models

\begin{tabular}{ccccccc}
\hline \hline \multirow{2}{*}{ Trait } & \multicolumn{5}{c}{ Mathematical models } \\
\cline { 2 - 7 } & Model 1 & Model 2 & Model 3 & Model 4 & Model 5 & Model 6 \\
\hline BMS No. & 0.43 & 0.43 & 0.43 & 0.43 & 0.43 & 0.43 \\
CW & 0.49 & 0.47 & 0.46 & 0.45 & 0.47 & 0.45 \\
REA & 0.32 & 0.32 & 0.33 & 0.32 & 0.32 & 0.32 \\
RT & 0.33 & 0.32 & 0.31 & 0.31 & 0.31 & 0.31 \\
SFT & 0.47 & 0.46 & 0.46 & 0.46 & 0.46 & 0.46 \\
\hline
\end{tabular}

BMS No. : Beef Marbling Standard Number; CW : Carcass weight; REA : Rib-eye area RT : Rib thickness ; SFT : Subcutaneous fat thickness.

びCWに関してはほぼ同じ値を示し，REAおよびRTに 関してはやや低く，SFTに関してはやや高かった。よっ て，これらの産肉性形質に関する遺伝率推定値は中程度 からやや高めであるといえる，また，全体のデー夕を用 いた場合は，モデルが違っても遺伝率推定値は非常に安 定していた.

しかし，全データから抽出したサンプル集団の遺伝率 推定値について Friedman 検定を行った結果, CW, RTお よびSFTにおいて数学モデル間で遺伝率推定値に $5 \%$ 水 準で有意差が認められた。とくに，有意差が認められた 3 形質においてモデル 1 は，ほとんどのサンプルで1番 高い遺伝率を推定していた. よって, 推定される遺伝率 の大きさに数学モデル間で, ある一定の傾向がみられ, 有意差が検出されたものと考えられる. また, BMS No. に関する予測育種価の順位が数学モデル間で大きく異な る種雄牛の例を表 7 に示した。例えば，予測育種価にお けるモデル間のばらつきが一番大きかった種雄牛 Aの 予測育種価はモデル1を用いた場合+1.1で順位は 158 位であったが，モデル 4 を用いた場合＋0.2で順位は 616 位であった. BMS No. に関しての予測育種価のモデ ル間差が 0.9 もあるのは大きい差であると考えられる. また，ある種雄牛 K の CWに関する予測育種価はモデル 1 を用いた場合 $+31.4 \mathrm{~kg}$ で順位は 89 位であり, モデル 4 を用いた場合 $+1.5 \mathrm{~kg}$ で順位は 636 位であった。このよ うに，予測育種価が数学モデル間で大きく異なる種雄牛
がいずれの形質についても存在した。これらの結果は, デー夕構造を考慮して, 全国評価に適した数学モデルを 選択することが重要であることを示唆している。 また， 予測育種価におけるモデル間の差異は, 多くの種雄牛に おいてモデル 1 とその他のモデルの間で一番大きく, 主 効果として要因の組み合わせ効果を取り上げるか否かが 予測育種価に影響を及ぼすと考えられた。

PEV, AIC およびR'先指標に用いて行った数学モデル 間の比較の結果を表 8 に示した. PEVに関しては, 形質 ごとモデルごとにすべての種雄牛のPEVの平均値およ び標準偏差を算出した.PEV を指標とした場合，よ゙の形 質に関してもモデル 6 あるいはモデル 4 のPEV の值が 小さく, それらの適合性が他のモデルと比べて高いと推 察される. AIC を指標とした場合も，ほぼ同様の結果が 得られ，SFT 以外の形質に関しては，概ねモデル 6 ある いはモデル 4 の AIC の值が小さく, それらの適合性が他 のモデルと比べて高い. AIC は，デー夕に対するモデル の当てはまり具合を表す尤度に，モデルに含まれる独立 変数の水準数に応じてペナルティーを科すというモデル の適合性を比較するための指標である（Wada と Kashiwagi 1990). モデル 6 はすべての主効果を, またモデル 4 は性以外のすべての効果を組み合わせ効果として取り 上げたモデルであるので, 必然的にその他のモデルより も独立変数の水準数が多くなる.しかし，SFTにおいて モデル 6 の適合性が順位にして 5 番目である以外は，モ 
小谷・中岡・成田・揖斐・佐々江・佐々木

Table 7. Rank of sire based on the predicted breeding value for BMS No.

\begin{tabular}{ccccccc}
\hline \hline \multirow{2}{*}{ Sire } & \multicolumn{5}{c}{ Rank $^{\mathrm{a})}$} \\
\cline { 2 - 7 } & Model 1 & Model 2 & Model 3 & Model 4 & Model 5 & Model 6 \\
\hline A & 158 & 174 & 590 & 616 & 156 & 616 \\
B & 167 & 197 & 501 & 499 & 194 & 458 \\
C & 143 & 267 & 541 & 520 & 309 & 460 \\
D & 338 & 274 & 702 & 659 & 257 & 664 \\
E & 10 & 22 & 36 & 44 & 22 & 44 \\
F & 17 & 18 & 27 & 52 & 37 & 52 \\
G & 11 & 11 & 33 & 28 & 17 & 32 \\
H & 228 & 218 & 442 & 458 & 233 & 471 \\
I & 248 & 154 & 151 & 83 & 157 & 80 \\
J & 212 & 266 & 424 & 427 & 333 & 499 \\
\hline
\end{tabular}

a) Total number of the evaluated sires was 1,513 . Ten Sires only are shown.

BMS No. : See the footnote in Table 6.

デル 6 およびモデル 4 の適合性は高く順位付けされてい る.また, $R^{2}$ を指標とした場合もモデル 6 およびモデル 4 の寄与率がどの形質に関しても高く，それらの適合性 が他のモデルと比べて高かった。一般に寄与率は独立変 数の水準数を増やせば増やすほど 1 に近づく．その水準 数のモデル間での差を式（5）により調整するが，デー夕 数 (49,810 頭) に対して水準数 (BMS No. の場合, 最多 でモデル 6 の 1,295 個，最少でモデル 1 の 176 個であ る. 形質によって共変量の取り上げ方で土2の差がある) がそれほど多くないために，自由度調整後でもモデル適 合性の順位がほぼ数学モデルを水準数の多い順に並べた ものになっていると考えられる.ここで, 式 (3)よりPEV と予測育種価の正確度には直接の関連があり，種牛評価 の観点からはPEVがもっとも重視されるべき指標であ ると考えられる。 また，モデル間比較の指標として $R^{\prime 2}$ を用いて行った結果は，PEVを用いて行った結果と形質 ごとに大きく矛盾するものではなかったＡIC に関して は，その尤度部分が表現型值の大きさ自体に依存するこ とが示唆され, モデル間比較の指標としてこの種の研究 に適用すべきかどうか今後検討の余地があると考えられ る. したがって, PEV および $R^{\prime 2} の$ 点から最適モデルと 判断されたすべての主効果を組み合わせ効果として取り 上げたモデル，もしくは性の効果のみを組み合わせ効果 から外したモデルが最適なモデルであると推察される.

2 つの肥育農家における出荷年の BLUE の年次変化を BMS No. とCW の場合について図1に示した. なお，出 荷年と肥育農家の組み合わせ効果が必要となるので,

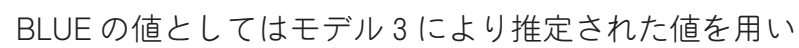
た. BMS No.およびCWに関してその年次変化を比較 すると，互いにその傾向が有意に異なる肥育農家が存在 していた. BMS No.について, 肥育農家の 610 および
702 における BLUE の値の出荷年に対する回帰係数はそ れぞれ-0.465，0.172であり，それらの回帰係数間には 5\%水準で有意差が認められた。また，CWについても， 肥育農家の 102 および 300 における BLUE の值の出荷年 に対する回帰係数はそれぞれ-4.55，8.04であり，それ らの回帰係数間には $5 \%$ 水準で有意差が認められた。従 来からの環境要因をそれぞれ主効果として取り上げた解 析（佐々木と佐々江 1988）においては，その年次変化が 全ての肥育農家において同じパターンであるということ が前提であった。しかし，その年次変化の傾向が肥育農 家によって異なる場合，その要因を単独で主効果として 取り上げたモデルを用いると評価に偏りが生じると考え られる.

ここに示した結果は, 母数効果間の交互作用効果が有 意であることを示唆するものである，また，モデル 2 か らモデル 6 に取り上げられた組み合わせ効果は, 各母数 効果の主効果および各母数効果間の 2 次から 3 次, 4 次 までの交互作用効果の両方を含むものであり，前述のよ うに要因を組み合わせ効果としてモデルに取り上げたモ デル 4 あるいは 6 が最適であったことと考え合わせる と, 広域での種牛評価のためのモデルでは, 交互作用効 果を考慮する必要があるものと推察される.

数学モデルの中に母数効果として, 出荷月を取り上げ るかどうかは議論の分かれるところであるが, 枝肉単価 などの経済的な指標ではなく枝肉形質という生物学的な 形質のみを扱ったために，ここでは月の効果は取り上げ なかった.しかし，BMS No. については出荷頭数や枝肉 市況などによって影響される可能性もあるので，さらに 今後検討する予定である.

以上の結果より，(有)安愚楽共済牧場から出荷される 肥育牛の枝肉デー夕の場合, 遺伝的結合度や遺伝率推定 
Table 8. Model comparison using PEV, AIC and R'2 as indicators of goodness of fit for carcass traits

\begin{tabular}{|c|c|c|c|c|c|c|c|}
\hline \multirow[b]{2}{*}{ Trait } & \multirow[b]{2}{*}{ Model } & \multicolumn{2}{|c|}{ PEV } & \multicolumn{2}{|r|}{ AlC } & \multicolumn{2}{|r|}{$\mathrm{R}^{\prime 2}$} \\
\hline & & Mean \pm S.D. & $\begin{array}{l}\text { Rank of } \\
\text { goodness of fit }\end{array}$ & Value & $\begin{array}{c}\text { Rank of } \\
\text { goodness of fit }\end{array}$ & Value & $\begin{array}{c}\text { Rank of } \\
\text { goodness of fit }\end{array}$ \\
\hline \multirow[t]{6}{*}{ BMS No. } & 1 & $0.735 \pm 0.363$ & 6 & 89911.00 & 4 & 0.302 & 6 \\
\hline & 2 & $0.709 \pm 0.349$ & 5 & 89955.65 & 5 & 0.325 & 5 \\
\hline & 3 & $0.692 \pm 0.340$ & 3 & 88765.49 & 1 & 0.330 & 4 \\
\hline & 4 & $0.672 \pm 0.327$ & 1 & 89614.51 & 2 & 0.343 & 2 \\
\hline & 5 & $0.706 \pm 0.347$ & 4 & 90083.75 & 6 & 0.333 & 3 \\
\hline & 6 & $0.673 \pm 0.327$ & 2 & 89850.60 & 3 & 0.350 & 1 \\
\hline \multirow[t]{6}{*}{ CW } & 1 & $647.090 \pm 329.393$ & 6 & 410912.55 & 6 & 0.510 & 6 \\
\hline & 2 & $602.545 \pm 303.248$ & 5 & 406989.94 & 4 & 0.527 & 4 \\
\hline & 3 & $569.140 \pm 283.420$ & 3 & 407353.80 & 5 & 0.526 & 5 \\
\hline & 4 & $548.514 \pm 271.670$ & 2 & 403218.21 & 2 & 0.542 & 2 \\
\hline & 5 & $584.705 \pm 292.355$ & 4 & 405657.84 & 3 & 0.530 & 3 \\
\hline & 6 & $541.950 \pm 267.892$ & 1 & 401816.47 & 1 & 0.548 & 1 \\
\hline \multirow[t]{6}{*}{ REA } & 1 & $9.783 \pm 4.506$ & 6 & 227063.27 & 6 & 0.233 & 6 \\
\hline & 2 & $9.445 \pm 4.321$ & 3 & 225969.85 & 4 & 0.249 & 5 \\
\hline & 3 & $9.589 \pm 4.408$ & 5 & 226033.55 & 5 & 0.255 & 4 \\
\hline & 4 & $9.160 \pm 4.166$ & 2 & 224831.72 & 2 & 0.272 & 2 \\
\hline & 5 & $9.452 \pm 4.320$ & 4 & 225749.27 & 3 & 0.259 & 3 \\
\hline & 6 & $9.156 \pm 4.161$ & 1 & 224591.06 & 1 & 0.276 & 1 \\
\hline \multirow[t]{6}{*}{ RT } & 1 & $0.151 \pm 0.0698$ & 6 & 26849.87 & 4 & 0.338 & 6 \\
\hline & 2 & $0.142 \pm 0.0643$ & 5 & 27174.93 & 5 & 0.364 & 4 \\
\hline & 3 & $0.134 \pm 0.0603$ & 3 & 25775.59 & 1 & 0.364 & 4 \\
\hline & 4 & $0.130 \pm 0.0583$ & 2 & 26399.05 & 2 & 0.393 & 2 \\
\hline & 5 & $0.139 \pm 0.0633$ & 4 & 27403.57 & 6 & 0.371 & 3 \\
\hline & 6 & $0.129 \pm 0.0576$ & 1 & 26801.50 & 3 & 0.400 & 1 \\
\hline \multirow[t]{6}{*}{ SFT } & 1 & $0.192 \pm 0.0970$ & 6 & 20718.18 & 2 & 0.405 & 6 \\
\hline & 2 & $0.180 \pm 0.0898$ & 5 & 21563.13 & 4 & 0.418 & 5 \\
\hline & 3 & $0.177 \pm 0.0890$ & 3 & 20049.04 & 1 & 0.421 & 3 \\
\hline & 4 & $0.173 \pm 0.0860$ & 2 & 21434.57 & 3 & 0.440 & 2 \\
\hline & 5 & $0.178 \pm 0.0890$ & 4 & 21996.92 & 6 & 0.421 & 3 \\
\hline & 6 & $0.172 \pm 0.0855$ & 1 & 21934.15 & 5 & 0.444 & 1 \\
\hline
\end{tabular}

BMS No., CW, REA, RT, SFT : See the footnotes in Table 6.

PEV : Prediction error variance.

AIC : Akaike's information criterion.

$\mathrm{R}^{\prime 2}$ : Coefficient of determination adjusted for the degrees of freedom.

値の点から, 全国的な種牛評価に利用できることが示さ れた。 その評価に当たっては, デー夕の中に雌肥育牛が 十分な頭数存在し解析対象亡なる場合は, 性の効果をも 含め, すべての環境要因を組み合わせ効果として取り上 げたモデルが，去勢肥育牛のみが解析対象の場合は，性 以外の環境要因を組み合わせ効果として取り上げたモデ ルが適切であると推察される.

本研究の結果は, 全国で県ごとに収集されている枝肉
市場記録に，(有)安愚楽共済牧場から出荷される肥育牛 の枝肉デー夕記録を統合することによって，黒毛和種集 団全体をカバーする広域での種牛評価が可能であること を示唆している.

\section{謝 辞}

本研究の遂行に当たり, 分析に対して貴重な助言をい ただいた佐賀大学農学部教授, 和田康彦先生に感謝の意 
i ) BMS No.

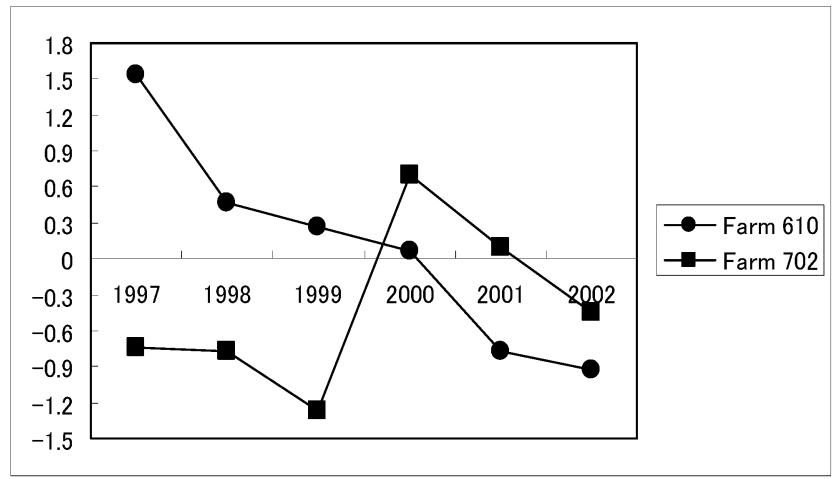

Farm $610: r=-0.465$

Farm 702:r $=0.172$

ii ) Carcass weight ( $\mathrm{kg})$

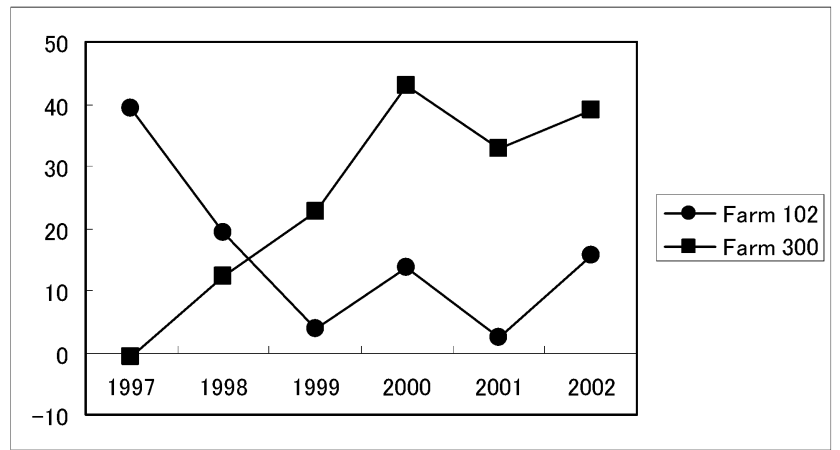

Farm 102: $r=-4.55$

Farm $300: r=8.04$

Fig. 1. Annual trends of BLUE for BMS No. and carcass weight related to shipping years for certain fattening farms.

BMS No. : See the footnote in Table 6.

$r$ : linear regression coefficient on shipping year.

を表します。

\section{文献}

Akaike H. 1973. Information theory and an extension of the maximum likelihood principle. In : Second international symposium on information theory. (Petrov BN, Csaki F eds.) Akademiai Kaido. Budapest. Reprinted in Breakthroughs in statistics, Vol. 1. (Kotz S, Johnson NL eds.) Springer-Verlag. New York.

Boldman KG, Kriese LA, Van Vleck LD, Van Tassell CP, Kachman SD. 1995. A Manual for Use of MTDFREML. A Set of Programs to Obtain Estimates of Variances and Covariances. U.S. Department of Agriculture, Agricultural Research Service. Washington, DC. USA.

Henderson CR. 1973. Sire evaluation and genetic trends. Proceeding of the Animal Breeding and Genetics Symposium in Honor of Dr. Jay L. Lush, 10-41. ASAS and ADSA Champaign. Illinois. USA.

Henderson CR. 1976. Best Linear Unbiased Prediction of breeding values not in the model for records. Journal of Dairy Science, $60: 783-787$.

市原清志. 2001. バイオサイエンスの統計学. 第 14 版. 171201. 南江堂. 東京.

磯貝 保・遠藤秀紀・谷口康子・吉田みその・木村和生・池内 豊・吉臭 努・白井達夫. 1993. 乳用牛の遺伝的能力評価
に適用するアニマルモデル。 日本畜産学会報, $64 ： 953-$ 963.

Kennedy BW, Trus D. 1993. Considerations on genetic connectedness between management units under an animal model. Journal of Animal Science, $71:$ 2341-2352.

Moriya K, Takayanagi S, Sasaki Y. 1998. GLMTEST- programs for hypothesis test of fixed effects in mixed model. Proceedings of the $6^{\text {th }}$ World Congress on Genetics Applied to Livestock Production, $27:$ 469-470.

向井文雄. 1994. 黒毛和種の産肉形質の選抜法ならびに遺伝的 評価に関する研究. 日本畜産学会報, 65：890-905.

野村哲郎・林 浩・佐々木義之. 1987. 中国地方における黒毛 和種集団の繁殖構造と遺伝学的分析. 日本畜産学会報, 58 : 21-27.

野村哲郎・佐々木義之. 1988。黒毛和種における増殖県の集団 構造ならびにそれらと種牛供給県との間の血縁度. 日本畜 産学会報, 59:880-889

Patterson HD, Thompson R. 1971. Recovery of interblock information when block sizes are unequal. Biometrika, $58: 545$ 554.

Robertson A, Rendel JM. 1954. The performance of heifers got by artificial insemination. The Journal of Agricultural Science, Cambridge, $44:$ 184-192.

Roso VM, Schenkel FS, Miller SP. 2002. Estimation of the degree of connectedness between test groups of station-tested 
beef bulls. Proceedings of the $7^{\text {th }}$ World Congress on Genetics Applied to Livestock Production, 29 : 549-552.

佐々木義之. 1989. 肉牛における種畜評価法の理論 (4). 畜産の 研究, $43: 1217-1223$.

佐々木義之. 1991. 肉牛における種牛評価システム (9). 畜産の 研究, $45: 535-542$.

佐々木義之. 1998. 動物遺伝育種学実験法 (佐々木義之編) 第 1 版. 86. 朝倉書店. 東京.

佐々木義之・佐々江洋太郎. 1988. フィールド記録を用いた BLUP 法による肉用種種雄牛評価のためのモデルの検討. 日本畜産学会報, $59:$ 23-30.

高柳誠二・守屋和幸・野村哲郎・道後泰治・佐々木義之. 1996. 兵庫県における黒毛和種の集団構造. 日本畜産学会 報, $67:$ 286-290.
丹後俊郎. 2000. 統計モデル入門 第 1版. 44-46. 朝倉書店. 東京.

Wada Y, Kashiwagi N. 1990. Selecting statistical models with information statistics. Journal of Dairy Science, 73 : 35753582.

Weigel KA, Rekaya R, Zwald NR, Fikse WF. 2001. International genetic evaluation of dairy sires using a multiple-trait model with individual animal performance records. Journal of Dairy Science, $84:$ :2789-2795.

Wood CM, Christian LL, Rothschild MF. 1991. Use of an animal model in situation of limited subclass numbers and high degrees of relationship. Journal of Animal Science, 69 : $1420-1427$.

\title{
A National Genetic Evaluation of Carcass Traits for the Japanese Black Cattle is Possible
}

\author{
Motoi ODANI, Hirofumi NAKAOKA, Akira NARITA, Takayuki IBI ${ }^{1}$, Yotaro SASAE ${ }^{1}$ and Yoshiyuki SASAKI
}

Graduate School of Agriculture, Kyoto University, Sakyo-ku, Kyoto-shi 606-8502, Japan

${ }^{1}$ Agura Kyosai Bokujo, Inc., Kuroiso-shi 325-0033, Japan

Corresponding : Yoshiyuki SASAKI (fax : +81 (0) 75-753-6340, e-mail : sasaki@kais.kyoto-u.ac.jp)

Comparisons of breeding stock among the Japanese Black cattle across regions were impeded because breeding programs and genetic evaluations were carried out primarily within regions. A nationwide connectedness was missing. The objective of this study was to investigate the possibility of a national genetic evaluation of breeding stocks based on appropriate mathematical models and suited material. Goodness of fit of the models was measured by the prediction error variance, the Akaike's information criterion and coefficient of determination. The data consisted of field records on carcass traits (beef marbling standard number, BMS No. ; carcass weight, CW ; rib-eye area, REA ; rib thickness, RT ; subcutaneous fat thickness, SFT) of fattened Japanese Black cattle collected from 1997 to 2002 among the nationwide fattening farms of Agura Kyosai Bokujo, Inc. $(N=49,810)$. The pedigree of those animals was surveyed, too. More than $95 \%$ of all possible pairs of fattening farms have beef animals with common sires. Further beef animals from different prefectures were dispersed over fattening farms so that comparisons among all prefectures were possible. Six mathematical models were applied, which differed in the way how each of the fixed effects was taken into account. The estimated heritabilities do not vary significantly among the applied mathematical models ( $h^{2}$ for BMS No. : 0.43 ; CW : 0.45-0.49; REA : 0.32-0.33; RT : $0.31-0.33$; SFT : 0.46-0.47). The models with the best goodness of fit are obtained when all the fixed effects are taken into account as a combination effect or when all the fixed effects but the effect of sex are taken into account as a combination of them. We were able to demonstrate that the genetic connectedness among subpopulations is sufficient in the involved fattening farms in order to establish a genetic evaluation on a national scale. A nationwide evaluation of the Japanese Black breeding stocks will enhance the genetic improvement of the breed by a more efficient selection of excellent sires and dams.

Nihon Chikusan Gakkaiho, 75 (3) : 353-361, 2004

Key words : Japanese Black cattle, National genetic evaluation, Predicting model, Genetic connectedness 